\title{
Company Constitutionalism?
}

Freedom Inside the Organization: Bringing Civil Liberties to the Workplace. By David W. Ewing. New York: E. P. Dutton, 1977. Pp. $\mathrm{x}, 246 . \$ 10.00$.

\section{Reviewed by Staughton Lynd ${ }^{\dagger}$}

Mr. Ewing's thesis is that employees should be guaranteed some of the same civil liberties at work that they enjoy, at least in theory, away from the workplace. "Once a U.S. citizen steps through the plant or office door at 9 A.M.," Mr. Ewing observes, "he or she is nearly rightless until 5 P.M., Monday through Friday."1

Much of this book is written in what one can only assume to be executive patois, with cheery little aphorisms like "I am a small part of my company, but my company is a big part of me,"' or "[i]t's not the size of the dog in the fight, but the size of the fight in the dog that counts."3 The analysis draws support from oversimplified history ("Evolution, not revolution, has been the story of rights in America"4), a diagram of the hierarchy of human needs, from Level 1 through Level $5,{ }^{5}$ and repeated citation of the same handful of cases; and stop signs appear when the discussion threatens to become too heavy ("we must be able to conceive of employee rights as a sound and productive part of the profitmaking process or we cannot make a strong case for them" ").

Style notwithstanding, the substance of Mr. Ewing's argument deserves close attention. The central idea in itself is not original. ${ }^{7} \mathrm{Mr}$. Ewing, however, has had the patience and courage to spell out in considerable detail a proposed employee bill of rights.

Mr. Ewing's view of workplace civil liberties can be gleaned from a number of partial lists at various points in the book. He deals ini-

+ Member, Illinois and Ohio Bars.

1. D. Ewing, Freedom Inside the Organization: Bringing Civil Liberties to the. WORKPLACE 3 (1977) [hereinafter cited by page number only].

2. P. 73.

3. P. 83.

4. P. 218 .

5. P. 48.

6. P. 66.

7. See, e.g., Seligman, Free Speech in the Workplace, The NATION, Nov. 27, 1976, at 562. 
tially with the panoply of First Amendment freedoms. To guard freedom of speech, he asserts, "[n]o organization or manager shall discharge, demote, or in other ways discriminate against any employee who criticizes, in speech or press, the ethics, legality, or social responsibility of management actions." 8 But speech should not be protected when it "rail[s] against the competence of a supervisor or senior manager to make everyday work decisions that have nothing to do with the legality, morality, or responsibility of management actions."' As to freedom of conscience, Mr. Ewing advocates that an employee should be able to refuse to carry out an order that he or she sincerely and reasonably believes to be unethical. "On the other hand, the boss should immediately be free to ask someone else to do the job." 10 Also,

[s]o long as their activities do not cause palpable harm to the organization, [employees] should be free to buy whatever products and services they wish from whatever source; they should be free to work for political, community, and social causes of their own choice; they should be free to engage in whatever other outside activities satisfy them. ${ }^{11}$

Mr. Ewing then explicates the right to privacy in considerable detail. He first sets out a series of guidelines for management's collection and retention of information. For example, management should collect and keep in its personnel files only those facts about employees that are required by law or that are necessary to manage operations. Performance evaluations more than three years old should be weeded out from an employee's file, and employees should be entitled to know what information about them is on tile and how it is being used. An employee should be entitled to see most of the information on file about him or her, although an employee should not have access to "personal evaluations and comments by other employees which could not reasonably be obtained if confidentiality were not promised." 12 Reflecting post-Watergate ethics, Mr. Ewing recommends that employees' conversations (including telephone) and meetings should not be taped or monitored without the consent of the employees. Nor should an employer be entitled to check up on an employee's absence by calling the employee's home and quizzing whoever answers the
8. P. 146 .
9. Pp. 109-10.
10. P. 119.
11. P. 123.
12. P. 149. 
phone or by sending an investigator to birddog the absentee. In an employee's absence, mail addressed to him or her may be opened only by a person in authority and envelopes marked "Personal" may not be opened by anyone in the organization. Finally, Mr. Ewing seeks to apply the Fourth Amendment to the workplace by suggesting that, "[w]hen an employee is away, his desk and personal office files may be opened only by someone in authority who is looking for specific items of information needed for operations." 13

Mr. Ewing would restrict management's use as well as collection of information. He recommends that no fact in an employee's file be furnished to an outsider without the employee's consent or a court order. "In other words, the employer has a fiduciary relationship to the employee, much as a lawyer does to his client or a doctor to his patient." 11 To adapt the employee's right to privacy to employer needs, Mr. Ewing suggests that employee information should be divided into two categories: job-related and personal. An employee's supervisors should have access only to job-related data. Personal data should be seen only by "personnel officials." 1 s And, to prevent altering of a worker's performance record by doctoring of his files, no information about an employee should be destroyed without his consent. ${ }^{16}$

Mr. Ewing would also accord to workers a third set of liberties that he characterizes as due process rights, such as the right to notice: "An employee who is discharged, demoted, or transferred to a less desirable job is entitled to a written statement from management of its reasons for the penalty." 17 Mr. Ewing would also ensure that "[e]very employee who feels that he or she has been penalized for asserting any right described in this bill shall be entitled to a fair hearing before an impartial official, board, or arbitrator. The findings and conclusions of the hearing shall be delivered in writing to the employee and management." 18

Mr. Ewing's bill of rights has some important omissions. In seeking to protect speech that criticizes the ethics, legality, or social responsibility of management actions, Mr. Ewing's concern is for speech about corporate action damaging to the public. Mr. Ewing eulogizes employees who sought to keep their companies from polluting ${ }^{19}$ and

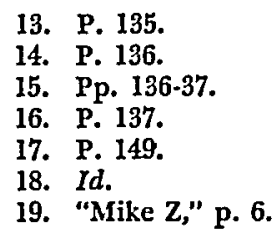


who tried to bring to public attention the defective condition of the buses they drove. ${ }^{20}$ He praises workers who refused to record conversations with prospective clients ${ }^{21}$ or to dump toxic materials into the Cuyahoga River,22 as well as those who took affirmative action and "blew the whistle" on improper practices of their governmental employers ${ }^{23}$ or who published an article critical of the company in a community newspaper. ${ }^{24}$ In short, Mr. Ewing defends employees who have acted like Ralph Nader at the risk of losing their jobs.

Mr. Ewing is much less interested when workers criticize their own exploitation. Indeed, he is inclined to fire them when they do.

Protection does not extend to employees who make nuisances of themselves or who balk, argue, or contest managerial decisions on normal operating and planning matters. . . . Nor does the protection extend to individuals who malign the organization. We don't protect individuals who go around ruining other people's reputations, and neither should we protect those who vindictively impugn their employers. ${ }^{25}$

The analogy of speech critical of a corporation to libel of an individual is especially unfortunate. With regard to speech outside the workplace, the nation has painfully come to the conclusion that penalizing criticism of individual governmental officials-the crime of seditious libel-has no place in the law of the First Amendment. ${ }^{26}$ Criticism of the boss is the seditious libel of the workplace. For Mr. Exving it remains a crime, justifying discharge-industry's form of capital punishment.

In other ways, too, Mr. Ewing's concept of free speech in the workplace is significantly less protective than that already sanctioned by the Supreme Court. Outside the workplace, as previously indicated, Mr. Ewing would permit an employee to speak and associate freely unless the activity caused "palpable harm to the organization." Inside the workplace, Mr. Ewing would restrain speech considered by management to constitute railing, vindictive impugning, balking, and other nebulously defined misdeeds without requiring the employer

20. A driver, p. 7 .

21. Shirley Zinman, p. 8.

22. A steel worker, pp. 18-19.

23. Ernest Fitzgerald, p. 78.

24. Michael Holodnak, p. 79.

25. Pp. 146-47.

26. See New York Times Co. v. Sullivan, 376 U.S. 254 (1964); Kalven, The New York Times Case: $A$ Note on "The Central Meaning of the First Amendment," 1964 Sup. Cr. REv. 191, 204-05 (1964). 
to show that the speech, however irritating, also caused palpable harm. The Supreme Court, on the other hand, has found speech in both the private and public workplaces to be protected unless it causes tangible disruption..$^{27}$ Moreover, Mr. Ewing proposes a constitutional amendment to create free speech rights in the workplace without mentioning that the Supreme Court has already held that, within the jurisdiction of the National Labor Relations Board, an employee's right to free speech is inalienable in the sense that a union cannot bargain it away. ${ }^{2 s}$

Similarly, Mr. Ewing's notion of conscientious objection predates development of this concept in selective service cases growing out of the Vietnam War. He would require "that the conscientious objector ... hold to a view that has some public acceptance. Fad moralitiesmessages from flying saucers, mores of occult religious sects, and so on-do not justify refusal to carry out an order." 29 By contrast, since United States $v$. Seeger, ${ }^{30}$ a conscientious objector to military service has been required to show only that "a given belief that is sincere and meaningful occupies a place in the life of its possessor parallel to that filled by the orthodox belief in God of one who clearly qualifies for the exemption." 31

The limitations of Mr. Ewing's approach become especially apparent when one turns to enforcement of procedural rights. Mr. Ewing has a tendency to equate "senior managers" with impartial magistrates. Thus he considers it the functional equivalent of a magistrate's search warrant if a "senior manager . . . has sound reason to believe that the [absent employee's] files contain information needed for a management decision." 32 The hearing Mr. Ewing has in mind would ordinarily be a hearing "in the employer organization" 33 presided over by officers of the very company that initiated the discipline at issue. Wherever the hearing is held, moreover, in Mr. Ewing's view it should lack certain rights considered integral to due process outside the workplace.

27. See Tinker v. Des Moines Independent Community School Dist., 393 U.S. 503, 513 (1969) (school pupils could not be suspended for wearing armbands when action did not materially and stubstantially disrupt operation of school); Pickering v. Board of Educ., 391 U.S. 563, 572-73 (1968) (public school teacher's statements did not warrant his dismissal where they did not interfere with operation of schools); Republic Aviation Corp. v. NLRB, 324 U.S. 793, 803 (1945) (upholding presumption that rules against union solicitation are invalid in absence of proof of necessity for maintaining production and discipline).

28. See NLRB v. Magnavox Co., 415 U.S. 322, 325-26 (1974) (union may not enter agreement with employer limiting in-plant communications).

29. P. 148 .

30. 380 U.S. 163 (1965).

31. Id. at 166 .

32. P. 148.

33. P. 235. 
The employee is guilty until proven innocent. "The burden should be on him or her to offer clear and convincing evidence. It should not be up to the employer to prove that the discharge was for incompetence, laziness, or economic reasons. If the burden of proof is on the employer, managers will be inhibited from building the most able and efficient staffs they can." ${ }^{3}$

There is no right to judgment by a jury of one's peers. The closest Mr. Ewing comes to the Sixth Amendment is to praise a procedure in one company where the employee appears before "five non-management employees, chosen at random," who in turn report their findings of fact to the company president, who "renders a decision." 35

There is no equality before the "law of the workplace." Nothing in Mr. Ewing's book begins to suggest that a "senior manager" who vindictively impugned an employee would be subject to the same summary discharge as an employee who rails against a boss, or that a supervisor starting a fight would be evenhandedly disciplined under the shop rule prohibiting fighting by hourly workers.

Mr. Ewing, then, sacrifices workplace civil liberties when they threaten to cut too sharply into managerial efficiency. He also fails to recognize that the arguments that underlie extending such liberties to industrial relations at all-the predominant role of the job in each worker's life and the fundamental human need for self-development and independence-also support establishment of a more democratic structure for all decisions made in the workplace. The logical conclusion of his reasoning is not, as Mr. Ewing contends, autocratic management limited by specific rights. Rather, it is some form of workplace democracy where the employees themselves decide not only what civil liberties should be protected but also how leisure should be balanced against income, whether better working conditions are worth some loss of profits, and how the work itself should be done.

Part of Mr. Ewing's unwillingness to push his thesis farther seems to be based on a foreshortened sense of history. Repeatedly he insists that lack of democracy in the workplace has become a concern "only in recent years;"36 that prior to the 1950s "employee constitutionalism was hypothetical"; 37 that in the nineteenth century "[p]erhaps the most important source of support of employer prerogatives was the attitude of employees. Poorly educated, poorly trained, and poorly motivated,

34. P. 202.

35. P. 161 .

36. P. 5.

37. P. 16. 
as a rule, they were content to let wisdom and insight reside in the heads of organizations." 38

This picture of the past overlooks, first, the Jeffersonian sentiment that there can be no democracy unless every man is his own boss and that factory labor is a form of slavery. Early in the industrial revolution, American workers responded to the factory system with demands for more freedom at work..$^{39}$ More immediately pertinent, Mr. Ewing's notion that efforts to bring constitutional liberties to the workplace began in the 1950s distorts history. By far the strongest thrust in recent years toward both workplace democracy and employee civil liberties coincided with the CIO insurgency in the years 1935-1947. The 1950s represented the quiescence of this movement, not its birth.

During the New Deal years, labor won a wide variety of employee liberties. Under section 7 of the National Labor Relations Act, workers attained the right to associate for mutual aid or protection, a workplace analogue of the First Amendment right, and the right to be represented by agents of their own choosing, an equivalent for the Sixth Amendment right to counsel. ${ }^{40}$ In a series of dramatic Supreme

38. P. 35 (emphasis in original).

39. For instance, Seth Luther, in his Address to the Working Men of New England, denounced the "prisons of New England called cotton mills." See 1 P. FonER, History of the Labor Movement in the UNited States 106 (1947). Striking mill girls themselves appealed to newspaper editors "opposed to the system of slavery attempted to be established in our manufacturing establishment." Id. at 109. During a strike of children for the reduction of the work day to 11 hours, a committee of workingmen from a neighboring city reported that conditions in the Paterson mills

belong rather to the dark ages than to the present times, and would be more congenial to the climate of his majesty the emperor and autocrat of all of the Russias, than this "land of the free and the home of the brave," this boasted asylum for the oppressed of all nations.

Id. at 111 .

Several recent studies have traced this sentiment into the second half of the nineteenth century. Alan Dawley, for example, describes the century-long militance of the shoemakers of Lynn, Massachusetts. In 1870, a Labor Reform convention sponsored by the Knights of St. Crispin declared:

We claim, that although the masses have advanced towards independence, they will never be completely free from vassalage until they have thrown off the system of working for hire. Men working for wages are, in greater or less degree, in the bonds of serfdom. The demand and supply of labor makes them the football of circumstances. Today, independent of all appearance; tomorrow, the veriest slave, begging for work, that he may carn a crust to sustain a miserable existence.

A. Dawley, Class and Community: The Industrial. Revolution in Lynn 198 (1976). Summarizing, Professor Dawley declares that "facile generalizations about the popular acceptance of business leadership at all levels of life and notions of America as a middleclass socicty do not square with examples like Lynn," and he notes that labor maintained a similarly extensive influence in other industrial communities throughout the nation. Id. at 228 .

40. National Labor Relations Act of 1935, $\$ 7$, Pub. L. No. 74-198 (current version codified at 29 U.S.C. $\$ 157$ (1970)). 
Court cases, employees won the First Amendment right to free speech in and near the workplace. ${ }^{41}$

Any doubt about whether the congressional mandate and these court decisions reflected a desire to extend constitutional rights to the workplace is settled by examining the NLRB briefs in such cases as Republic Aviation. ${ }^{42}$ Drawing on First Amendment ideas just then gaining currency from the Supreme Court decisions concerning the Jehovah's Witnesses, ${ }^{43}$ the Board successfully argued to the Court that section 7 should be read to incorporate the concepts of overbreadth, of chilling effect, and of the irrelevance of alternative speech opportunities. Furthermore, section 7 would require a showing of substantial and material disruption-the workplace equivalent of clear and present danger-before speech might be restrained. ${ }^{44}$ The same concepts have subsequently been elaborated in public employee speech cases, such as Pickering $v$. Board of Education, ${ }^{45}$ which upheld the right of a teacher to criticize school board policy. But, contrary to Mr. Ewing's view of history, the Court in that case adopted ideas already well established in the private sphere more than twenty years earlier.

Mr. Ewing's disregard for the union movement and its judicial achievements suggests a disturbing thought. Perhaps Mr. Ewing's constitutionalism-without-unions is a resurrection of the movement for "industrial democracy," more aptly characterized as company unionism, that flourished in the 1920s."6 Perhaps what Mr. Ewing is advocating is a way for companies to head off unionism among their employees by creating from above a facsimile of the rights unionism would provide.

Let us consider, in fairness, the rebuttals that Mr. Ewing might offer to this hypothesis. If the creation of unions were strictly limited and

41. These decisions included Hague v. CIO, 30 † U.S. 496 (1939) (municipal streets and parks are public forums subject to First Amendment easement); Marsh v. Alabama, 326 U.S. 501 (1946) (First Amendment also extends to similar areas in privately owned company town); Thomas v. Collins, 323 U.S. 516 (1945) (state may not impose prior restraint on First Amendment activity by requiring union organizers to be licensed); Thornhill v. Alabama, 310 U.S. 88,94 (1940) (pickets who "appear to have been on company property" were engaged in protected speech because "[i]n the circumstances of our times the dissemination of information concerning the facts of a labor dispute must be regarded as within that area of free discussion that is guaranteed by the Constitution"); and Republic Aviation Corp. v. NLRB, 324 U.S. 793 (1945) (employee speech on employer's property is presumptively protected if it occurs during nonworking time).

42. 324 U.S. 793 (1945).

43. See, e.g., Schneider v. State, 308 U.S. 147, 150 (1939) (municipality may not use police power in restraint of freedom of speech and press).

44. See Lynd, Employee Speech in the Private and Public Workplace: Two Doctrines or One?, 1 INDUS. REL. L.J. 711, 717-19 (1977).

45. 391 U.S. 563 (1968).

46. Cf. W. Lauck, Political and Economic Democracy, 1776-1926 (1926) (compendium of "employee representation" plans). 
if most workers were obligated to remain unorganized, there might be cause for focusing on the implementation of specific rights to the exclusion of unionization. Mr. Ewing rightly points out that fifty million employees in the private sector do not belong to unions. He also observes correctly that in its recent Bell Aerospace decision, ${ }^{47}$ the Supreme Court held that managerial employees are not covered by the National Labor Relations Act. ${ }^{48}$ But the bulk of nonunionized employees in the private sector are covered by the National Labor Relations Act and their obvious first step toward civil liberties in the workplace would be to seek collective bargaining recognition.

Again rightly, Mr. Ewing indicates that many unions "seem to be as despotic and corrupt as the worst corporate management teams" and that union organizations "are subject to the same managerial diseases as other types of organizations." ${ }^{9}$ These are reasons to wage a vigorous struggle for internal union democracy. They are not reasons for preferring a company-initiated grievance plan to a union as a means of protecting employee rights against management.

In addition, the civil liberties Mr. Ewing is most concerned to protect are not necessarily protected by section 7 of the National Labor Relations Act, because section 7 protects protest only when it is related to wages, hours, and working conditions, and is the concerted action of more than one person. Hence the single person seeking to prevent a company from marketing an unsafe product may get no help from the Board. Mr. Ewing performs a service in highlighting the plight of such individuals. Surely, however, protection should be extended to persons thus situated in addition to the more prosaic safeguards provided by unions, rather than as an alternative to unionism.

Mr. Ewing's strongest rebuttal to the charge of antiunionism is a passage in which he advocates that unions bargain collectively for civil liberties.

Is there any reason that employee unions or associations cannot write civil liberties into the contract? Apparently this step has not yet been taken. Judging from the general trend in collective bargaining, however, there seems to be no reason that it cannot be done-and the movement is unmistakably in this direction. For example, unions have been going outside the conventional scope of work conditions and dealing with problems of sexism in the office. ... Also, unions are becoming ever more conscious of the

47. NLRB v. Bell Aerospace Co., 416 U.S. 267 (1974).

48. Public supervisory and managerial employees can join unions under the laws of some states. See, e.g., Seattle v. Amalgamated Transit Union Local 587, No. 44441 (Washington Sup. Ct. Aug. 25, 1977).

49. Pp. 165-66. 
rights of minorities, as spelled out in the Fourteenth and Fifteenth Amendments to the Constitution. If union officials consider rights like these important, surely they can add others to the list..$^{50}$

This is a most creative suggestion and, whatever may be Mr. Ewing's overall views about unions, it deserves to be pursued. In my judgment, Mr. Ewing is quite right to believe that bargaining for civil liberties is at the edge of the possible. In the recent contest for president of the United Steelworkers of America, both candidates espoused the idea that an employee should be innocent until proven guilty: that is, the employee should remain at his or her job, at regular pay, until any discipline sought by management has been finally adjudicated. ${ }^{51}$

Perhaps the best way to sum up the sense in which Mr. Ewing is antiunion is to clarify the degree to which he is promanagement. The parameters of this book were established by polls and surveys addressed by Mr. Ewing to corporate executives; 52 its audience, clearly, is management (see, for example, Chapter 4: "Are Employee Rights A Threat To Capitalism?"). Mr. Ewing believes that rights can be established for individual employees without changing the fundamental allocation of power between management and labor. Inevitably, then, he must persuade himself that powver will yield without a demand: that the corporate hierarchy, guided by enlightened self-interest, will itself set in motion the changes needed to make the work environment more decent and humane. This is paternalism. Even if feasible, Mr. Ewing's program would be humiliating to workers in a way that Mr. Ewing does not seem to perceive. And implementation of the program is not possible, because, on Mr. Ewing's logic, decency must give way when it conflicts with profit.

In short, Mr. Ewing's constitutionalism is constitutional monarchy. Mr. Ewing expressly rejects the idea that individual rights must be protected by democratic self-government: the idea, in the words of the Declaration of Independence, that "to secure these rights, governments are instituted among men, deriving their just powers from the consent of the governed." According to Mr. Ewing:

No realist will argue that companies, government bureaus, and other public agencies should be run democratically. ${ }^{53}$

Employees accept that management must manage, that the boss

50. P. 164 .

51. See The Youngstorwn Vindicator, Sept. 28, 1976, at 21; id., Feb. 7, 1977, at 15.

52. Mr. Ewing polled the 3,500-plus subscribers of the Harvard Business Review in 1971 and again in 1977. See pp. 18, 25 n.12, 118-19.

53. P. 21 . 


\section{Company Constitutionalism}

has to make planning and operating decisions. This understanding comes as naturally as that a football or baseball team can't operate democratically. ${ }^{54}$

Of course, it would be unperceptive and unrealistic to try to apply the Bill of Rights across the board. Companies and public organizations cannot be run like democracies, their officials elected by ballot, their directives subjected to referendum, their day-to-day decisions debated-at least, not if they are also to be efficient. ${ }^{\mathbf{5 5}}$

Such is the view from the Harvard Business School. But it is not the view from the assembly lines and blast furnaces, where thoughtful men and women are convinced that work goes better when the foreman is sick and will tell you of the endless inefficiency and unresponsiveness to suggestion of those who give them orders. Any philosophy of employee rights that is to take root and grow in this ultimately democratic country must speak for, and be accountable to, employees themselves.
54. P. 42.
55. P. 218. 